\title{
The Increase of Short-term Heat Exposure Temperature at Extreme Range Decreased Phosphofructokinase-1 Activity and AMPK Phosphorylation in Postmortem Chicken Breast Muscle
}

\section{Mingyue Zhang}

Shandong Agricultural University

Chaoyu Zhai

Colorado State University https://orcid.org/0000-0001-5148-4584

Xin Luo

Shandong Agricultural University

Hai Lin

Shandong Agricultural University

Minghao Zhang

Shandong Agricultural University

Lixian Zhu

Shandong Agricultural University

Mahesh N. Nair

Colorado State University

Rongrong Liang ( $\nabla$ rrliang@sdau.edu.cn )

Shandong Agricultural University

Short report

Keywords: chicken, pectoralis major, short-term heat exposure, AMPK, glycolysis

Posted Date: November 11th, 2020

DOI: https://doi.org/10.21203/rs.3.rs-104071/v1

License: (c) (i) This work is licensed under a Creative Commons Attribution 4.0 International License.

Read Full License 


\section{Abstract}

Preslaughter exposure to high ambient temperature could accelerate postmortem glycolysis and impair chicken breast (pectoralis major muscle) quality. However, previous studies indicated that it might be different when the temperature of short-term heat exposure (SHE) raises to extreme range (above $38^{\circ} \mathrm{C}$ ). Therefore, the objectives of this study were to evaluate the effect of SHE in the range of extreme temperatures $\left(36^{\circ} \mathrm{C}, 38^{\circ} \mathrm{C}\right.$, and $\left.40^{\circ} \mathrm{C}\right)$ on the activity of glycolytic enzymes and AMP-activated protein kinase (AMPK) in postmortem muscles. The activity of key glycolytic enzymes and phosphorylation of Threonine 172 in AMPK a subunit (p-AMPK-a[Thr172]) during early postmortem $(0.1,1,2$, and $4 \mathrm{~h}$ ) and the muscle $\mathrm{pH}$ decline $(0.1,1,2,4$, and $24 \mathrm{~h})$ were evaluated. SHE did not affect $(P>0.05)$ glycogen phosphorylase a (GPa) and pyruvate kinase (PK) activity within $4 \mathrm{~h}$ postmortem. However, the phosphofructokinase-1 (PFK-1) activity and phosphorylation of AMPK-a[Thr172] decreased $(P<0.05)$ as antemortem SHE temperature increased from $36^{\circ} \mathrm{C}$ to $40^{\circ} \mathrm{C}$, which could explain the faster $\mathrm{pH}$ decline in the $36^{\circ} \mathrm{C}$ group at $1 \mathrm{~h}$ and $2 \mathrm{~h}$ postmortem $(P<0.05)$, and it could be attributed to proteotoxic stress response resulting from extreme heat exposure. Hexokinase (HK) activity was also affected by the SHE temperature $(P<0.05)$ with the $36^{\circ} \mathrm{C}$ group having the highest $(P<0.05)$ activity within $4 \mathrm{~h}$ postmortem. The results of the current study, for the first time, indicated that the increase of antemortem SHE temperature at extreme range does not always accelerate the $\mathrm{pH}$ decline rate and increase postmortem glycolytic enzyme activity and AMP-activated protein kinase phosphorylation and that the postmortem metabolism is dependent on SHE temperature. Further research is necessary to explore the biochemical basis of this temperature-dependent $\mathrm{pH}$ decline, glycolytic enzyme activity, and AMPK phosphorylation.

\section{Backgrounds}

Pale, soft, and exudative (PSE) meat is a quality defect of chicken breast associated with abnormally light color, soft texture, and poor water holding capacity that has become one of the biggest challenges to the poultry industry worldwide [1-3]. The conversion of muscle to meat during the early postmortem period is a short but intensive period accompanied by severe changes in metabolism [4,5]. Rapid glycolysis and $\mathrm{pH}$ decline during the early postmortem period is considered to be one of the major reasons for PSE meat [6].

AMP-activated protein kinase (AMPK) is an energy status sensor that maintains cellular energy homeostasis [7] and is a mediator of proteotoxic stress response [8]. The maximal AMPK activity is initiated by the phosphorylation of the amino acid Threonine 172 in the AMPK a subunit (p-AMPK$\mathrm{a}[\mathrm{Thr172]}$ [9]. Previous studies have indicated that an increased expression of p-AMPK-a[Thr172] at early postmortem is associated with rapid glycolysis and $\mathrm{pH}$ decline at postmortem, which can lead to meat quality defects [10-15]. The activated AMPK can, in turn, accelerate postmortem phosphofructokinase-2 (PFK2) activity [16], an enzyme that catalyzes the production of fructose-2,6 bisphosphate (F-2, 6-BP) to further activate phosphofructokinase-1 (PFK1) [17-19]. 
The incidence of PSE could be increased by heat stress (exposure to high ambient temperature) in birds $[20,21]$, probably due to the altered metabolism, acid/base status, oxidative reactions, and changes in hormonal secretions [22]. Although several studies have examined the influence of acute heat stress ranging from $32{ }^{\circ} \mathrm{C}$ to $41^{\circ} \mathrm{C}$ on chicken breast quality [21, 23-29], inconsistent results were observed when the antemortem acute heat stress ranged from $36^{\circ} \mathrm{C}$ to $41^{\circ} \mathrm{C}[21,25,28,29]$. Meat quality, such as cooking loss, color attributes, and water holding capacity in chicken breast were impaired by one-hour antemortem acute heat stress at $36^{\circ} \mathrm{C}$ and $37^{\circ} \mathrm{C}[21,28]$ but not at $40{ }^{\circ} \mathrm{C}$ and $41^{\circ} \mathrm{C}[25,29]$.

Our recent study also indicated that poultry meat quality was affected by short-term heat exposure (SHE) of $36^{\circ} \mathrm{C}$, but exposure to temperatures above $38^{\circ} \mathrm{C}$ did not always lead to more pale and lower WHC breast meat [30]. Moreover, the breast meat quality defects were reduced as heat exposure temperatures raised from $36^{\circ} \mathrm{C}$ to $40{ }^{\circ} \mathrm{C}$ [30]. One possible explanation for this variation in meat quality with different exposure temperatures could be the change in of muscle metabolism postmortem [30]. However, the biochemical basis of this variation is not clearly understood. Therefore, the objectives of this study were to evaluate the changes in glycolytic enzyme activity and AMPK phosphorylation at early postmortem after antemortem short-term heat exposure (SHE) of $36^{\circ} \mathrm{C}, 38^{\circ} \mathrm{C}$, or $40^{\circ} \mathrm{C}$.

\section{Methods}

\section{Animal treatment and sampling}

One hundred male broilers (from Arbor Acres) were raised under similar conditions $\left(25^{\circ} \mathrm{C} \pm 1{ }^{\circ} \mathrm{C}, \mathrm{RH} 58 \%\right.$ $\sim 62 \%)$ for the first six weeks. Twenty-four broilers with similar weight $(2.32 \pm 0.02 \mathrm{~kg})$ were selected from those and eight broilers each $(n=8)$ were randomly assigned to either $(1) 36^{\circ} \mathrm{C}$ heat exposure, (2) $38^{\circ} \mathrm{C}$ heat exposure, or (3) $40{ }^{\circ} \mathrm{C}$ heat exposure for 90 minutes. All 24 broilers were moved to a preparation room $\left(25^{\circ} \mathrm{C}\right)$ and caged individually for 24 hours before the SHE for adaption. After the adaptation period, the broilers were moved into a heat exposure room for applying the treatments for $90 \mathrm{~min}$. All the cage positions in the heat exposure room were the same as in the preparation room, and water was offered throughout the treatment.

After 90 minutes of exposure, each broiler was moved out and then slaughtered and bled within five minutes. After exsanguination, boneless pectoralis major (PM) muscle from both sides of the bird was removed manually by knife cutting immediately, without scalding or defeathering, and stored at $4{ }^{\circ} \mathrm{C}$ for aging and analysis. Two grams of sample was collected from PM muscle from each side at $0.1 \mathrm{~h}, 1 \mathrm{~h}$, $2 \mathrm{~h}$, and $4 \mathrm{~h}$ postmortem for enzyme analysis or $\mathrm{pH}$ measurement. An additional sample from right breast muscle was collected at $24 \mathrm{~h}$ postmortem for the ultimate $\mathrm{pH}$ measurement. The collected samples were placed into $5 \mathrm{~mL}$ antifreeze tubes, frozen in liquid nitrogen, and stored at $-80^{\circ} \mathrm{C}$ until analysis.

\section{Muscle pH value}

The $\mathrm{pH}$ values of the right breast muscles were measured, according to Wang et al. [31]. One-gram muscle sample was homogenized in $9 \mathrm{~mL}$ of $5 \mathrm{mM}$ iodoacetate solution for $60 \mathrm{~s}$ by a blender (IKA, T18, 
Staufen, Germany) at medium speed. The $\mathrm{pH}$ was measured by a $\mathrm{pH}$ meter (SevenGo, Mettler Toledo, Zurich, Switzerland). The pH value was calculated from the average of the three repetitions.

\section{Enzyme activity measurement}

The activity of enzyme glycogen phosphorylase a (GPa) was measured because GPa is typically more active than glycogen phosphorylase $b$, and the latter form can be converted to GPa by phosphorylation [32] or calcium activation [33]. Glycogen phosphorylase a (GPa) activity was estimated spectrophotometrically using a glycogen phosphorylase assay kit (GPA-2-Y, Suzhou Comin Biotechnology Co. Ltd, Suzhou, China). Approximately $100 \mathrm{mg}$ sample was homogenized in $1 \mathrm{~mL}$ extraction solution. After centrifugation ( $8,000 \times \mathrm{g}$ at $\left.4{ }^{\circ} \mathrm{C}, 10 \mathrm{~min}\right), 10 \mu \mathrm{L}$ of the supernatant was mixed with $10 \mu \mathrm{L}$ distilled water and $180 \mu \mathrm{L}$ reaction mixture in a microvolume quartz cuvette and held at $37^{\circ} \mathrm{C}$. The absorbance values at $340 \mathrm{~nm}$ were recorded after $5 \mathrm{~min}$ (A1) and $10 \mathrm{~min}$ (A2). Protein concentration (Cpr) was determined using a BCA protein assay kit (BCAP-2-W, Suzhou Comin Biotechnology Co. Ltd, Suzhou, China). The activity of GPa was calculated as $(643 \times A) / C p r$ where $A=A 2-A 1$.

Hexokinase $(\mathrm{HK})$ activity was determined spectrophotometrically with a hexokinase assay kit (HK-2-Y, Suzhou Comin Biotechnology Co. Ltd, Suzhou, China). Approximately $100 \mathrm{mg}$ of sample was homogenized in $1 \mathrm{~mL}$ extraction solution. After centrifugation (8,000 $\times \mathrm{g}$ at $\left.4{ }^{\circ} \mathrm{C}, 10 \mathrm{~min}\right), 30 \mu \mathrm{L}$ of the supernatant was mixed with $1008 \mu \mathrm{L}$ reaction mixture in a quartz cuvette and held at $37^{\circ} \mathrm{C}$. The absorbance values at $340 \mathrm{~nm}$ were recorded after $20 \mathrm{~s}$ (A1) and 5 min $20 \mathrm{~s}$ (A2). Protein concentration (Cpr) was determined using a BCA protein assay kit (BCAP-2-W, Suzhou Comin Biotechnology Co. Ltd, Suzhou, China). The activity of HK was calculated as $(1113 \times A) / C p r$, where A = A1 - A2.

Phosphofructokinase-1 (PFK1) activity was determined spectrophotometrically with a phosphofructokinase-1 assay kit (PFK-2-Y, Suzhou Comin Biotechnology Co. Ltd, Suzhou, China). Approximately $100 \mathrm{mg}$ of sample was homogenized in $1 \mathrm{~mL}$ extraction solution. After centrifugation $\left(8,000 \times \mathrm{g}\right.$ at $\left.4{ }^{\circ} \mathrm{C}, 10 \mathrm{~min}\right), 30 \mu \mathrm{L}$ of the supernatant was mixed with $810 \mu \mathrm{L}$ reaction mixture in a quartz cuvette and held at $37^{\circ} \mathrm{C}$. The absorbance values at $340 \mathrm{~nm}$ were recorded after $20 \mathrm{~s}$ (A1) and $10 \mathrm{~min}$ $20 \mathrm{~s}$ (A2). Protein concentration (Cpr) was determined using a BCA protein assay kit (BCAP-2-W, Suzhou Comin Biotechnology Co. Ltd, Suzhou, China). The activity of PFK1 was calculated as $(450 \times A) / C p r$, where $A=A 1-A 2$.

Pyruvate kinase (PK) activity was determined spectrophotometrically with a pyruvate kinase kit (PK-2-Y, Suzhou Comin Biotechnology Co. Ltd, Suzhou, China). Approximately $100 \mathrm{mg}$ of sample was homogenized in $1 \mathrm{~mL}$ extraction solution. After centrifugation (8,000 $\times \mathrm{g}$ at $\left.4{ }^{\circ} \mathrm{C}, 10 \mathrm{~min}\right), 50 \mu \mathrm{L}$ of the supernatant was mixed with $950 \mu \mathrm{L}$ reaction mixture in a quartz cuvette and held at $37^{\circ} \mathrm{C}$. The absorbance values at $340 \mathrm{~nm}$ were recorded after $20 \mathrm{~s}$ (A1) and $2 \mathrm{~min} 20 \mathrm{~s}$ (A2), respectively. Protein concentration (Cpr) was determined using a BCA protein assay kit (BCAP-2-W, Suzhou Comin Biotechnology Co. Ltd, Suzhou, China). The activity of PK was calculated as $(2613 \times A) / C p r$, where $A=A 1$ $-\mathrm{A} 2$.

\section{Immunoblot analysis for phosphorylation of AMPK}


The determination of p-AMPK-a[Thr172] was modified based on previous methods [14, 34]. Frozen muscle samples $(0.5 \mathrm{~g})$ were homogenized $(13,500 \times \mathrm{g}$ for $10 \mathrm{~s})$ using a polytron homogenizer (IKA Works, Inc., Wilmington, NC, USA) in $5 \mathrm{~mL}$ pre-cooled buffer containing $20 \mathrm{mmol} / \mathrm{L} \mathrm{Tris-HCl} \mathrm{(pH} 7.4$ at $\left.4{ }^{\circ} \mathrm{C}\right), 2 \%$ sodium dodecyl sulfate (SDS), $5 \mathrm{mmol} / \mathrm{L}$ ethylenediamine tetraacetic acid (EDTA), $5 \mathrm{mmol} / \mathrm{L}$ ethyleneglycoltetracatic acid (EGTA), $1 \mathrm{mmol} / \mathrm{L}$ dithiothreitol (DTT), $100 \mathrm{mM}$ sodium fluoride (NaF), $2 \mathrm{mmol} / \mathrm{L}$ sodium vanadate, $0.5 \mathrm{mmol} / \mathrm{L}$ phenylmethylsulfonyl fluoride (PMSF), $10 \mu \mathrm{g} / \mathrm{mL}$ leupeptin and $10 \mu \mathrm{g} / \mathrm{mL}$ pepstatin. Muscle homogenates were then centrifuged at $17,500 \times \mathrm{g}$ at $4{ }^{\circ} \mathrm{C}$ for $20 \mathrm{~min}$, and the supernatants were collected into fresh tubes. Protein concentration was determined by bicinchoninic acid (BCA) protein assay kit (Sigma, Dorset, UK).

For electrophoresis, each homogenate was mixed with an equal amount of $2 \times$ standard sample loading buffer and heated for $3 \mathrm{~min}$ in a dry heater $\left(100^{\circ} \mathrm{C}\right)$. Equal amounts of total protein $(45 \mu \mathrm{g})$ were resolved by electrophoresis (Bio-Rad, Richmond, CA, USA) on 10\% SDS-PAGE (polyacrylamide gel electrophoresis) before being transferred electrophoretically to a polyvinylidenefluoride (PVDF) membrane. The transfer was done with a transfer buffer containing $25 \mathrm{mmol} / \mathrm{L}$ Tris, $192 \mathrm{mmol} / \mathrm{L}$ glycine, 15\% (v/v) methanol, $0.01 \%(\mathrm{w} / \mathrm{v})$ SDS using $90 \mathrm{~V}$ for $90 \mathrm{~min}$ at $4{ }^{\circ} \mathrm{C}$. After transfer, the membranes were incubated in $5 \%$ nonfat dry milk in Tris-buffered saline with Tween-20 (TBST; $0.8 \% \mathrm{NaCl}(\mathrm{wt} / \mathrm{vol}), 0.02 \% \mathrm{KCl}$ (wt/vol), $0.24 \%$ Tris (wt/vol), 0.05\% Tween-20 (vol/vol)) for $1 \mathrm{~h}$. Primary antibody, phospho-AMPK-a[Thr172] antibody (Cell Signaling Technology, Beverly, MA, USA) or monoclonal anti-glyceraldehyde-3-phosphate dehydrogenase (GAPDH) antibody (Bio-world, St. Louis Park, MO, USA) was diluted in TBST. The PVDF membranes were incubated overnight at $4{ }^{\circ} \mathrm{C}$ with the primary antibody. The blots were washed and incubated for $1.5 \mathrm{~h}$ with a secondary antibody (Jackson, West Grove, PA, USA). After 30 min washing, membranes were visualized using ECL Western blotting reagents (Amersham Bioscience, Piscataway, NJ, USA) and exposed to film (MR; Kodak, Rochester, NY, USA). The band densities were quantified by using Imager Scanner II and Image Quantity One software (GE, CT, USA). Band density among different blots was normalized according to the density of the reference band.

\section{Statistical analysis}

A split-plot design was used to evaluate the effects of antemortem SHE temperature and postmortem time on muscle $\mathrm{pH}$, glycolytic enzyme activity, and AMPK phosphorylation. Samples were assigned to temperature x postmortem time combinations. Data analysis was performed by R (version 3.6.1) using the Ime4 package as a mixed model, where temperature, postmortem time, and their interactions were fixed effects, and the random effect in the model was the individual bird. Differences between leastsquare means $(P<0.05)$ were determined by Tukey's multiple comparisons.

\section{Results And Discussion}

\section{Muscle pH}

The muscle $\mathrm{pH}$ during the early postmortem in response to SHE is presented in Fig. 1. There was an interaction between temperature and postmortem time $(P<0.05)$. All the three temperature groups had 
same initial muscle $\mathrm{pH}$ at $0.1 \mathrm{~h}$ postmortem $(P>0.05)$, then the $\mathrm{pH}$ in $36^{\circ} \mathrm{C}$ group rapidly dropped from $0.1 \mathrm{~h}$ to $1 \mathrm{~h}$ postmortem and had a lower $\mathrm{pH}$ than the $40^{\circ} \mathrm{C}$ and $38^{\circ} \mathrm{C}$ group at $1 \mathrm{~h}$ and $2 \mathrm{~h}$ postmortem $(P<0.05)$. However, no difference was observed in $\mathrm{pH}$ among different temperature treatments at 4 and $24 \mathrm{~h}$ postmortem. A similar $\mathrm{pH}$ decline and ultimate $\mathrm{pH}$ values after $\mathrm{SHE}$ have been reported in previous studies as well [29-31]. This indicated that the increase of SHE temperature from $36^{\circ} \mathrm{C}$ to $40{ }^{\circ} \mathrm{C}$ caused a slower $\mathrm{pH}$ decline at early postmortem.

\section{Glycolytic Enzyme Activity}

The GPa activity during the early postmortem in response to SHE is presented in Fig. 2A. While there was no interaction between temperature and postmortem time $(P<0.05)$, a main effect of postmortem time $(P$ $<0.05)$ was observed for the GPa activity. Overall, the GPa activity decreased $(P<0.05)$ from $0.1 \mathrm{~h}$ to $4 \mathrm{~h}$. A similar trend of GPa activity in postmortem muscle has been reported by other researchers [6,35], which could be attributed to the $\mathrm{pH}$ decline from 6.8, the optimum environment $\mathrm{pH}$ for GPa activity [36]. However, the GPa activity within 4 hours postmortem was not $(P>0.05)$ influenced by the SHE temperatures used in the current study. On the other hand, a main effect of temperature $(P<0.05)$ was observed on the HK activity (Fig. 2B). The HK activity at $36^{\circ} \mathrm{C}$ was higher $(P<0.05)$ than the $38^{\circ} \mathrm{C}$ group; however, there was no difference $(P>0.05)$ between HK activity of the $40^{\circ} \mathrm{C}$ group and the $36^{\circ} \mathrm{C}$ or $38^{\circ} \mathrm{C}$ group. Moreover, the HK activity was influenced by the postmortem time $(P<0.05)$ with the activity increasing $(P<0.05)$ from $0.1 \mathrm{~h}$ to $2 \mathrm{~h}$ postmortem, followed by a decrease $(P<0.05)$ from $2 \mathrm{~h}$ to $4 \mathrm{~h}$ postmortem. A similar trend of HK activity in postmortem muscle has been reported by other researchers [35], which could be explained by the high residual activity of $\mathrm{HK}$ around $\mathrm{pH} 6.0$ [37].

The PFK1 activity during early postmortem time in response to SHE is presented in Fig. 2C. Both temperature and postmortem time influenced $(P<0.05)$ the PFK1 activity, with the activity decreasing $(P<$ $0.05)$ as time postmortem increased. The PFK 1 activity in $36^{\circ} \mathrm{C}$ group was higher $(P<0.05)$ than $40{ }^{\circ} \mathrm{C}$ group, but there was no difference between $38^{\circ} \mathrm{C}$ group and $36^{\circ} \mathrm{C}$ or $40^{\circ} \mathrm{C}$ group. This result indicated that the heat stress temperature affected PFK1 activity at early postmortem, and PFK1 activity was reduced by the increase of antemortem SHE temperature from $36^{\circ} \mathrm{C}$ to $40^{\circ} \mathrm{C}$. A similar temperature effect was also observed in a vitro system, which showed that PFK1 activity under $42{ }^{\circ} \mathrm{C}$ was lower than that under $33^{\circ} \mathrm{C}[6]$. Unlike PFK1, the PK activity at early postmortem was not $(P>0.05)$ influenced by the SHE (Fig. 2D). A main effect of postmortem time $(P<0.05)$ was observed with a decrease $(P<0.05)$ in PK activity from 0.1 and $1 \mathrm{~h}$ to $4 \mathrm{~h}$ postmortem, which could be attributed to the $\mathrm{pH}$ decline further from its optimum $\mathrm{pH}$ at mildly alkaline range [38, 39].

\section{Phosphorylation of AMPK}

The amount of p-AMPK-a[Thr172] during the early postmortem is shown in Fig. 3. Temperature influenced $(P<0.05)$ the amount of p-AMPK-a[Thr172] with the $36^{\circ} \mathrm{C}$ group having greater $(P<0.05)$ phosphorylation than the $40^{\circ} \mathrm{C}$ group, but there was no difference $(P>0.05)$ between $38^{\circ} \mathrm{C}$ group and $36{ }^{\circ} \mathrm{C}$ or $40^{\circ} \mathrm{C}$ group. This result indicated that the high temperature of antemortem SHE affected p- 
AMPK-a[Thr172] at early postmortem, and the phosphorylation decreased with increase in antemortem SHE temperature.

In addition, the postmortem time also influenced $(P<0.05)$ the p-AMPK-a[Thr172]. While the phosphorylation increased $(P<0.05)$ from $0.1 \mathrm{~h}$ to $1 \mathrm{~h}$ postmortem, it decreased $(P<0.05)$ from $1 \mathrm{~h}$ to $2 \mathrm{~h}$ postmortem. In agreement, previous research also reported that p-AMPK-a[Thr172] in chicken PM muscle treated by antemortem transport stress increased from $0.5 \mathrm{~h}$ to $1 \mathrm{~h}$, followed by a decrease to $4 \mathrm{~h}$ postmortem [11]. Moreover, similar trends in AMPK activity in postmortem muscle have been reported by other researchers $[16,40-44]$.

In the current study, changes in GPa, HK, and PK activity did not correspond with the changes in AMPK activation with different SHE. These results are in agreement with previous studies, which suggested that the AMPK activation cannot fully account for postmortem GPa $[16,35,40,43,44]$ and PK activity $[16,40$, 41]. However, our results demonstrated that the PFK1 activity corresponded with p-AMPK-a[Thr172] with both PFK1 activity and p-AMPK-a[Thr172] decreasing when temperature increased from $36^{\circ} \mathrm{C}$ to $40^{\circ} \mathrm{C}$. These results are also in agreement with previous studies suggesting that AMPK regulates postmortem glycolysis through PFK1 [16]. However, a recent study indicated that PFK1 can be directly increased by AMP, and this activation is more feasible than the activation by the p-AMPK induced fructose-2,6 bisphosphate (F-2, 6-BP) production [45]. It is also possible that decreased p-AMPK-a and PFK1 activity in $40^{\circ} \mathrm{C}$ as compared to $36^{\circ} \mathrm{C}$ group resulted from the difference in AMP content, but this possibility cannot be confirmed in the current study and needs further investigation. In addition, recent research pointed that PFK1 activity can affect glycolysis and ultimate $\mathrm{pH}$ in postmortem chicken PM muscle [46]. There was no difference in ultimate $\mathrm{pH}$ among different temperature groups in the current study, but the $36^{\circ} \mathrm{C}$ group had lower $\mathrm{pH}$ than other groups at $1 \mathrm{~h}$ and $2 \mathrm{~h}$ postmortem, which is possibly caused by increased PFK1 activity in the $36^{\circ} \mathrm{C}$ group at early postmortem.

To the best of our knowledge, the current study is the first one to report a lower PFK1 activity and phosphorylation of AMPK-a[Thr172] in chicken PM muscle from birds exposed to SHE of $40{ }^{\circ} \mathrm{C}$ compared to $36^{\circ} \mathrm{C}$. This decreased p-AMPK-a[Thr172] and PFK1 activity in the $40{ }^{\circ} \mathrm{C}$ group could be attributed to proteotoxic stress response due to preslaughter extreme heat exposure, which can inhibit p-AMPK$\mathrm{a}[\mathrm{Thr} 172]$ and activate heat shock factor 1 to increase the expression of heat shock proteins $[8,47]$, a set of proteins that can protect muscle cell from calcium overload, cell death signaling, and proteolysis and preserve meat quality [48]. In chicken PM muscle, heat shock protein 70 (Hsp70), a member of heat shock family, has been considered as a protective protein due to its higher abundance in normal meat than defective meat [49-51]. In support, previous research indicated that two-hour heat exposure under $40^{\circ} \mathrm{C}$ could increase the expression of Hsp70 in chicken breast muscle to more than three times [52], which suggests that SHE of $40^{\circ} \mathrm{C}$ might have increased the cellular defensive mechanism in chicken breast meat. Moreover, the chicken PM muscle after antemortem SHE of $40{ }^{\circ} \mathrm{C}$ exposure had better meat quality, less mitochondrial damage, greater protein solubility, and higher muscle fiber integrity as compared to SHE of $36^{\circ} \mathrm{C}$ [30]. Some studies have indicated that Hsp70 can directly interact with PFK1 in chicken PM muscle during the early postmortem period [49] and have a negative correlation with p-AMPK-a[Thr172] 
[13]. Hence, we believe that the increase of antemortem SHE temperature from $36^{\circ} \mathrm{C}$ to $40{ }^{\circ} \mathrm{C}$ might have stimulated the proteotoxic stress response in chicken PM muscle during the early postmortem, which could cause the decreased PFK1 activity, lower p-AMPK-a[Thr172], and slower pH decline. However, further research is necessary to explore the mechanism behind the decreased postmortem p-AMPKa[Thr172] and PFK1 activity due to antemortem extreme heat exposure.

\section{Conclusions}

The results from the current study demonstrated that antemortem SHE temperature could influence $\mathrm{pH}$ decline, AMPK activation, and glycolytic enzyme activity in chicken PM muscle at early postmortem. Specifically, the early postmortem PFK1 activity and p-AMPK-a[Thr172] decreased as antemortem SHE temperature increased from $36^{\circ} \mathrm{C}$ to $40{ }^{\circ} \mathrm{C}$, which could explain the faster $\mathrm{pH}$ decline in the $36^{\circ} \mathrm{C}$ group at $1 \mathrm{~h}$ and $2 \mathrm{~h}$ postmortem, and it could be attributed to proteotoxic stress response resulting from extreme heat exposure. $\mathrm{HK}$ activity was also affected by the SHE temperature with the $36^{\circ} \mathrm{C}$ group having the highest activity within $4 \mathrm{~h}$ postmortem. The SHE temperatures used in the current study did not influence the GPa and PK activity within $4 \mathrm{~h}$ postmortem. These results also for the first time indicated that the increase of antemortem SHE temperature does not always increase the $\mathrm{pH}$ decline rate, postmortem glycolytic enzyme activity, and AMP-activated protein kinase phosphorylation and that the postmortem metabolism is dependent on SHE temperature. The mechanisms behind this temperature-dependent $\mathrm{pH}$ decline, glycolytic enzyme activity, and AMPK activation need further investigation.

\section{Declarations}

\section{Ethical approval and consent to participate}

All animal experiments were reviewed and approved by the Institutional Animal Care and Use Committee of Shandong Agricultural University (No. 2001002) and performed in accordance with the "Guidelines for Experimental Animals" of the Ministry of Science and Technology (Beijing, China). All efforts were made to minimize the suffering of the animals.

\section{Competing interests}

The authors declare that they have no competing interests.

\section{Funding}

This work was funded by the National Natural Science Fund of China (31401518).

\section{Authors' contributions}


Conceptualization, Rongrong Liang; Methodology, Mingyue Zhang and Minghao Zhang; Formal Analysis, Mingyue Zhang; Investigation, Mingyue Zhang and Chaoyu Zhai; Resources, Hai Lin; Data Curation, Mingyue Zhang; Writing - Original Draft Preparation, Mingyue Zhang and Chaoyu Zhai; Writing - Review \& Editing, Xin Luo, Minghao Zhang, Lixian Zhu, Mahesh N. Nair, and Rongrong Liang; Visualization, Chaoyu Zhai; Supervision, Xin Luo; Project Administration, Rongrong Liang; Funding Acquisition, Rongrong Liang.

\section{Acknowledgements}

Not applicable.

\section{Availability of data and materials}

The datasets used and/or analysed during the current study are available from the corresponding author on reasonable request.

\section{Consent for publication}

Not applicable.

\section{References}

1. Owens $C M$, Alvarado CZ, Sams AR. Research developments in pale, soft, and exudative turkey meat in North America. Poultry Sci. 2009;88:1513-7.

2. Petracci M, Bianchi M, Cavani C. The European perspective on pale, soft, exudative conditions in poultry. Poultry Sci. 2009;88:1518-23.

3. Zhu X, Xu X, Min H, Zhou G. Occurrence and Characterization of Pale, Soft, Exudative-Like Broiler Muscle Commercially Produced in China. J Integr Agr. 2012;11:1384-90.

4. England EM, Scheffler TL, Kasten SC, Matarneh SK, Gerrard DE. Exploring the unknowns involved in the transformation of muscle to meat. Meat Sci. 2013;95:837-43.

5. Matarneh SK, England EM, Scheffler TL, Gerrard DE. Chapter 5 - The conversion of muscle to meat. In: Toldra' F, editor. Lawrie's Meat Science (Eighth Edition) [Internet]. Woodhead Publishing; 2017. p. $159-85$.

6. England EM, Matarneh SK, Scheffler TL, Wachet C, Gerrard DE. pH inactivation of phosphofructokinase arrests postmortem glycolysis. Meat Sci. 2014;98:850-7.

7. Garcia D, Shaw RJ. AMPK: Mechanisms of cellular energy sensing and restoration of metabolic balance. Mol Cell. 2017;66:789-800. 
8. Su K-H, Dai C. Metabolic control of the proteotoxic stress response: implications in diabetes mellitus and neurodegenerative disorders. Cell Mol Life 2016;73:4231-48.

9. Hawley SA, Davison M, Woods A, Davies SP, Beri RK, Carling D, et al. Characterization of the AMPactivated protein kinase kinase from rat liver and identification of threonine 172 as the major site at which it phosphorylates AMP-activated protein kinase. J Biol Chem. 1996;271:27879-87.

10. Huang JC, Yang J, Huang M, Zhu ZS, Sun XB, Zhang BH, et al. Effect of pre-slaughter shackling and wing flapping on plasma parameters, postmortem metabolism, AMPK, and meat quality of broilers. Poultry Sci. 2018;97:1841-7.

11. Jiang N, Xing T, Han M, Deng S, Xu X. Effects of water-misting sprays with forced ventilation on post mortem glycolysis, AMP-activated protein kinase and meat quality of broilers after transport during summer. Anim Sci J. 2016;87:718-28.

12. Lu Z, He X, Ma B, Zhang L, Li J, Jiang Y, et al. Chronic heat stress impairs the quality of breastmuscle meat in broilers by affecting redox status and energy-substance metabolism. J Agr Food Chem. 2017;65:11251-8.

13. Xing $T$, Xu XL, Zhou GH, Wang P, Jiang NN. The effect of transportation of broilers during summer on the expression of heat shock protein 70, postmortem metabolism and meat quality1. J Anim Sci. 2015;93:62-70.

14. Xing T, Xu X, Jiang N, Deng S. Effect of transportation and pre-slaughter water shower spray with resting on AMP-activated protein kinase, glycolysis and meat quality of broilers during summer. Anim Sci J. 2016;87:299-307.

15. Zhang L, Wang X, Li J, Zhu X, Gao F, Zhou G. Creatine monohydrate enhances energy status and reduces glycolysis via inhibition of AMPK pathway in pectoralis major muscle of transport-stressed broilers. J Agr Food Chem. 2017;65:6991-9.

16. Shen QW, Means WJ, Underwood KR, Thompson SA, Zhu MJ, McCormick RJ, et al. Early postmortem AMP-activated protein kinase (AMPK) activation leads to phosphofructokinase-2 and -1 (PFK-2 and PFK-1) phosphorylation and the development of pale, soft, and exudative (PSE) conditions in porcine longissimus muscle. J Agr Food Chem. 2006;54:5583-9.

17. Pilkis SJ, El-Maghrabi MR, Pilkis J, Claus TH, Cumming DA. Fructose 2,6-bisphosphate. A new activator of phosphofructokinase. J Biol Chem. 1981;256:3171-4.

18. Uyeda K, Furuya E, Luby LJ. The effect of natural and synthetic D-fructose 2,6-bisphosphate on the regulatory kinetic properties of liver and muscle phosphofructokinases. J Biol Chem. 1981;256:8394-9.

19. Van Schaftingen E, Jett MF, Hue L, Hers HG. Control of liver 6-phosphofructokinase by fructose 2,6bisphosphate and other effectors. Proc Natl Acad Sci USA 1981;78:3483-6.

20. Owens CM, Mckee SR, Matthews NS, Sams AR. The development of pale, exudative meat in two genetic lines of turkeys subjected to heat stress and its prediction by halothane screening. Poultry Sci. 2000;79:430-5. 
21. Wang RH, Liang RR, Lin H, Zhu LX, Zhang YM, Mao YW, et al. Effect of acute heat stress and slaughter processing on poultry meat quality and postmortem carbohydrate metabolism. Poultry Sci. 2017;96:738-46.

22. Zaboli G, Huang X, Feng X, Ahn DU. How can heat stress affect chicken meat quality? - a review. Poultry Sci. 2019;98:1551-6.

23. Debut M, Berri C, Baeza E, Sellier N, Arnould C, Guemene D, et al. Variation of chicken technological meat quality in relation to genotype and preslaughter stress conditions. Poultry Sci. 2003;82:182938.

24. Hu H, Bai X, Wen A, Shah AA, Dai S, Ren Q, et al. Assessment of interactions between glutamine and glucose on meat quality, AMPK, and glutamine concentrations in pectoralis major meat of broilers under acute heat stress. J Appl Poultry Res. 2016;25:370-8.

25. Northcutt JK, Foegeding EA, Edens FW. Water-Holding Properties of Thermally Preconditioned Chicken Breast and Leg Meat. Poultry Sci. 1994;73:308-16.

26. Sandercock DA, Hunter RR, Nute GR, Mitchell MA, Hocking PM. Acute heat stress-induced alterations in blood acid-base status and skeletal muscle membrane integrity in broiler chickens at two ages: Implications for meat quality. Poultry Sci. 2001;80:418-25.

27. Sifa D, Bai X, Zhang D, Hu H, Wu X, Wen A, et al. Dietary glutamine improves meat quality, skeletal muscle antioxidant capacity and glutamine metabolism in broilers under acute heat stress. J Appl Anim Res. 2018;46:1412-7.

28. Tang S, Yu J, Zhang M, Bao E. Effects of different heat stress periods on various blood and meat quality parameters in young Arbor Acer broiler chickens. Can J Anim Sci. 2013;93:453-60.

29. Wang RR, Pan XJ, Peng ZQ. Effects of heat exposure on muscle oxidation and protein functionalities of pectoralis majors in broilers. Poultry Sci. 2009;88:1078-84.

30. Zhang M, Zhu L, Zhang Y, Mao Y, Zhang M, Dong P, et al. Effect of different short-term high ambient temperature on chicken meat quality and ultra-structure. Asian-Austral J Anim. 2018;32:701-10.

31. Wang RH, Liang RR, Lin H, Zhu LX, Zhang YM, Mao YW, et al. Effect of acute heat stress and slaughter processing on poultry meat quality and postmortem carbohydrate metabolism. Poultry Sci. 2017;96:738-46.

32. Barford D, Johnson LN. The allosteric transition of glycogen phosphorylase. Nature. 1989;340:60916.

33. Meyer WL, Fischer EH, Krebs EG. Activation of skeletal muscle phosphorylase b kinase by $\mathrm{Ca}^{2+}$ * Biochemistry-US. 1964;3:1033-9.

34. Shen QW, Gerrard DE, Du M. Compound C, an inhibitor of AMP-activated protein kinase, inhibits glycolysis in mouse longissimus dorsi postmortem. Meat Sci. 2008;78:323-30.

35. Li Q, Li Z, Lou A, Wang Z, Zhang D, Shen QW. Histone acetyltransferase inhibitors antagonize AMPactivated protein kinase in postmortem glycolysis. Asian-Austral J Anim.2017;30:857-64. 
36. Kasvinsky PJ, Meyer WL. The effect of $\mathrm{pH}$ and temperature on the kinetics of native and altered glycogen phosphorylase. Arch Biochem Biophys. 1977;181:616-31.

37. Souza MA, Ribeiro MZ, Silva DP, Pessoa A, Vitolo M. Effect of pH on the stability of hexokinase and glucose 6-phosphate dehydrogenase. Appl Biochem Biotech. 2002;98:265-72.

38. Simon LM, Kotormán M, Szajáni B, Boross L. Comparative studies on soluble and immobilized rabbit muscle pyruvate kinase. Appl Biochem Biotech. 1985;11:195-205.

39. Brown CE, Taylor JM, Chan L-M. The effect of pH on the interaction of substrates and effector to yeast and rabbit muscle pyruvate kinase. BBA-Protein Struct 1985;829:342-7.

40. Shen QW, Du M. Role of AMP-activated protein kinase in the glycolysis of postmortem muscle. J Sci Food Agr. 2005;85:2401-6.

41. Shen QW, Du M. Effects of dietary a-lipoic acid on glycolysis of postmortem muscle. Meat Sci. 2005;71:306-11.

42. Du M, Shen QW, Zhu MJ. Role of $\beta$-Adrenoceptor signaling and AMP-activated protein kinase in glycolysis of postmortem skeletal muscle. J Agr Food Chem. 2005;53:3235-9.

43. Shen QW, Means WJ, Thompson SA, Underwood KR, Zhu MJ, McCormick RJ, et al. Pre-slaughter transport, AMP-activated protein kinase, glycolysis, and quality of pork loin. Meat Sci. 2006;74:38895.

44. Shen QW, Underwood KR, Means WJ, McCormick RJ, Du M. The halothane gene, energy metabolism, adenosine monophosphate-activated protein kinase, and glycolysis in postmortem pig longissimus dorsi muscle. J Anim Sci. 2007;85:1054-61.

45. Chauhan SS, LeMaster M, England EM. At physiological concentrations, AMP increases phosphofructokinase-1 activity compared to fructose 2, 6-bisphosphate in postmortem porcine skeletal muscle. Meat Sci. 2021;172:108332.

46. Matarneh SK, Yen C-N, Elgin JM, Beline M, da Luz e Silva S, Wicks JC, et al. Phosphofructokinase and mitochondria partially explain the high ultimate $\mathrm{pH}$ of broiler pectoralis major muscle. Poultry Sci. 2018;97:1808-17.

47. Dai S, Tang Z, Cao J, Zhou W, Li H, Sampson S, et al. Suppression of the HSF1-mediated proteotoxic stress response by the metabolic stress sensor AMPK. EMBO J. 2015;34:275-93.

48. Xing T, Gao F, Tume RK, Zhou G, Xu X. Stress Effects on Meat Quality: A Mechanistic Perspective. Compr Rev Food Sci F. 2019;18:380-401.

49. Xing T, Wang P, Zhao L, Liu R, Zhao X, Xu X, et al. A comparative study of heat shock protein 70 in normal and PSE (pale, soft, exudative)-like muscle from broiler chickens. Poultry Sci. 2016;95:23916.

50. Xing T, Wang MF, Han MY, Zhu XS, Xu XL, Zhou GH. Expression of heat shock protein 70 in transportstressed broiler pectoralis major muscle and its relationship with meat quality. Animal. 2017;11:1599-607. 
51. Xing T, Wang C, Zhao X, Dai C, Zhou G, Xu X. Proteome analysis using isobaric tags for relative and absolute analysis quantitation (iTRAQ) reveals alterations in stress-induced dysfunctional chicken muscle. J Agr Food Chem. 2017;65:2913-22.

52. Hao Y, Gu XH. Effects of heat shock protein 90 expression on pectoralis major oxidation in broilers exposed to acute heat stress. Poultry Sci. 2014;93:2709-17.

\section{Figures}

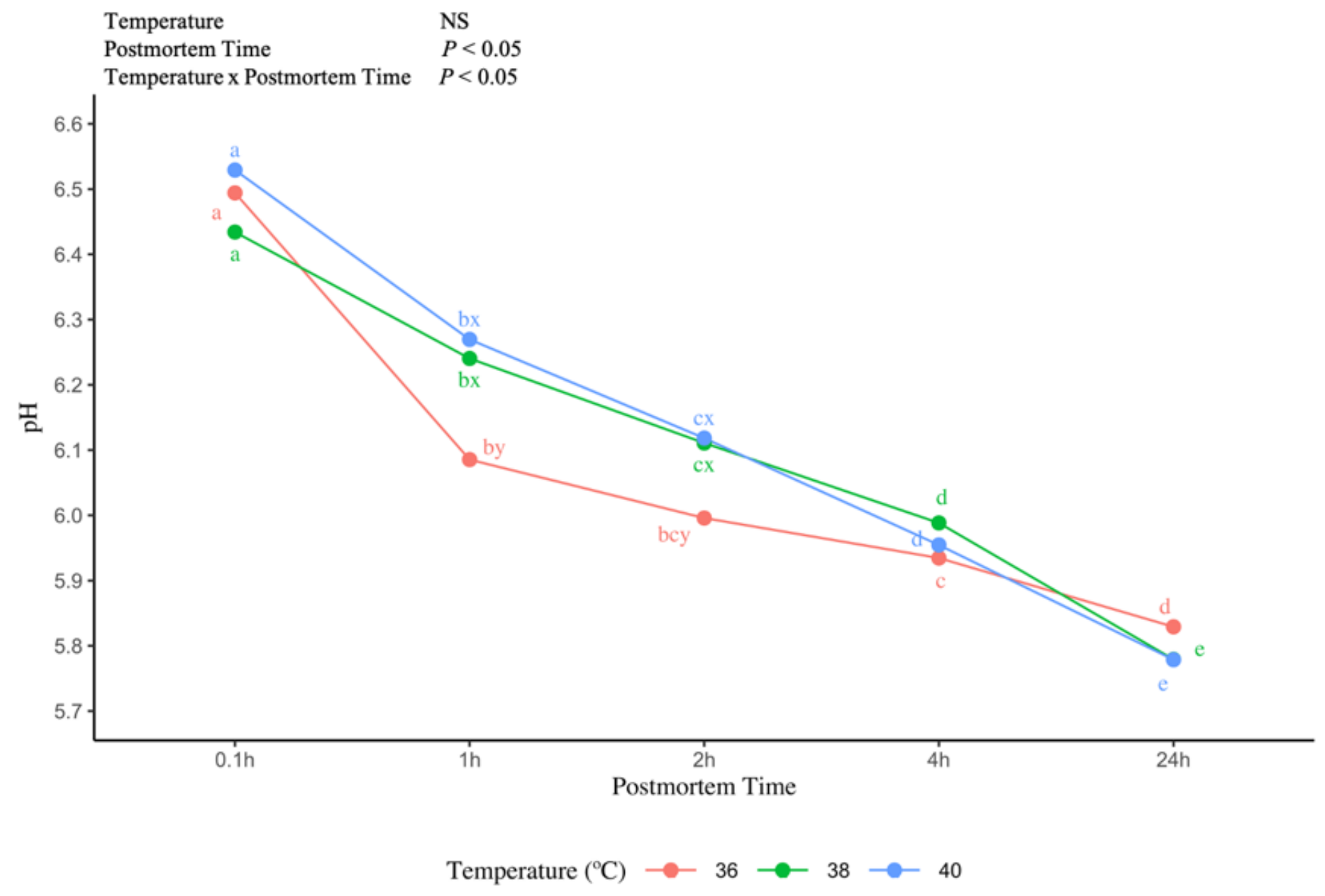

\section{Figure 1}

Effect of antemortem short-term heat exposure (SHE) and postmortem time on pH decline $(n=8)$ in chicken pectoralis major muscle. Least square means for the $\mathrm{pH}$ of different temperature groups at same postmortem time without a common letter $(x-y)$ differ $(P<0.05)$. Least square means for the $\mathrm{pH}$ of same temperature group at different postmortem time without a common letter $(a-c)$ differ $(P<0.05)$. Standard error for comparison $=0.0315$. Abbreviations: $\mathrm{NS}=$ no significance . 

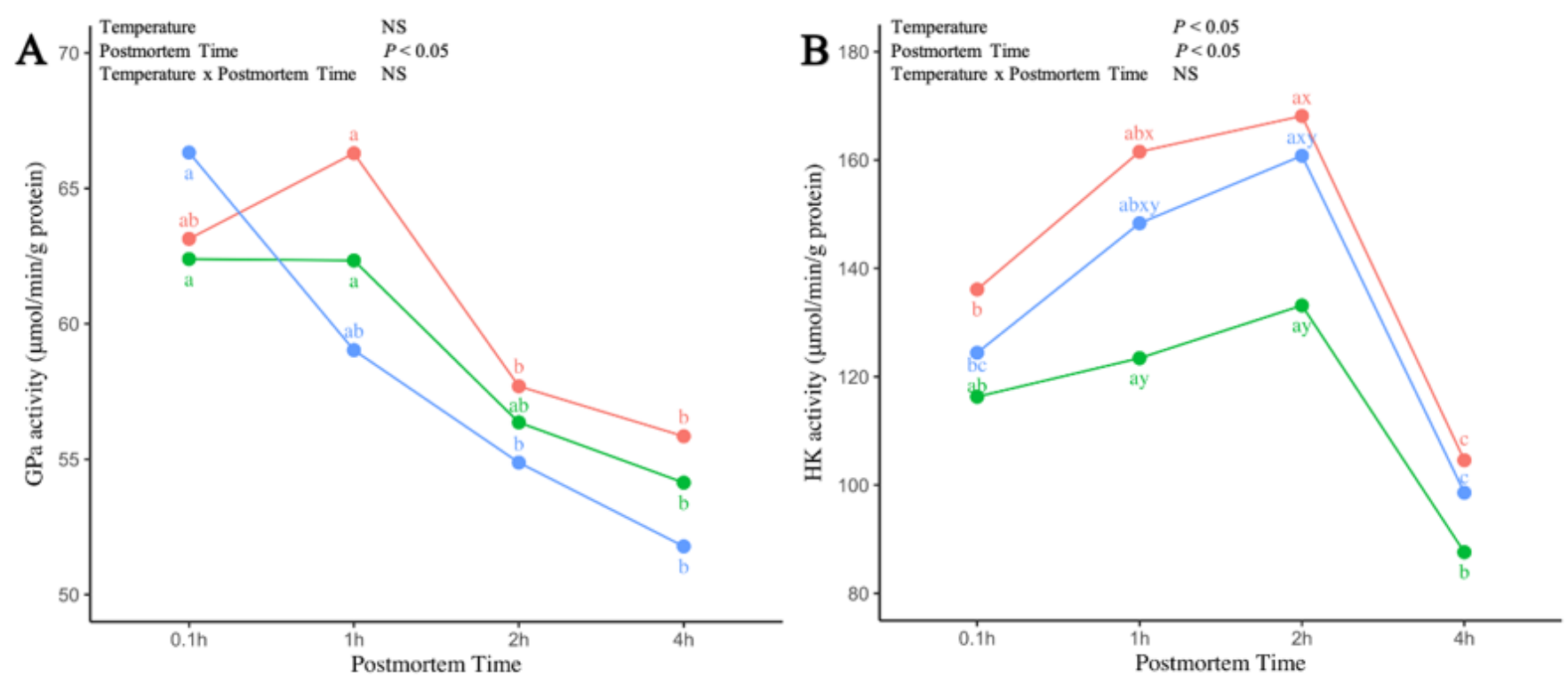

Temperature $\left({ }^{\circ} \mathrm{C}\right) \multimap 36 \multimap 38 \longrightarrow 40$
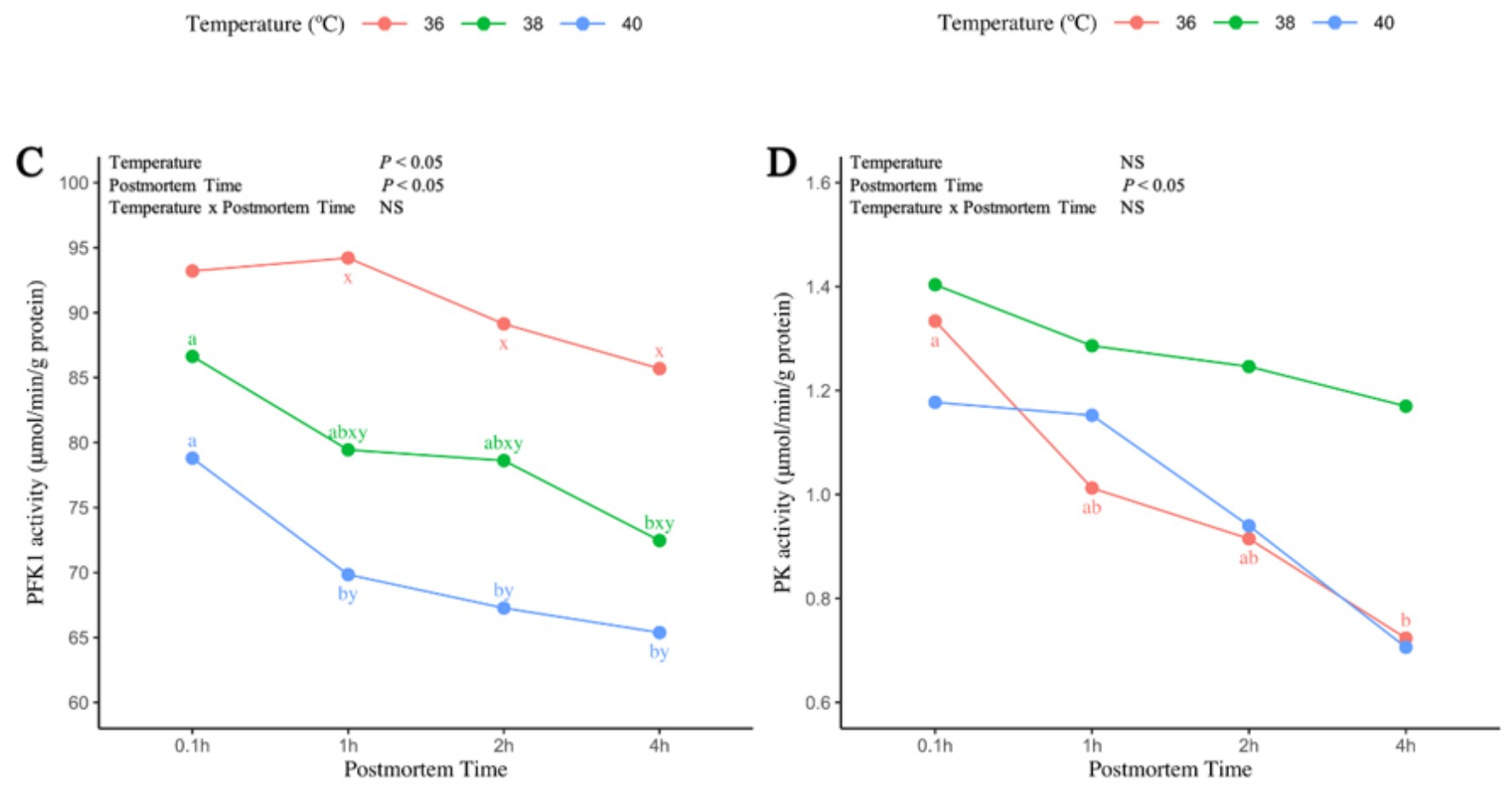

Temperature $\left({ }^{\circ} \mathrm{C}\right) \multimap 36 \multimap 38 \multimap-40$

Temperature $\left({ }^{\circ} \mathrm{C}\right) \multimap 36 \multimap 38 \multimap-40$

Figure 2

Effect of antemortem short-term heat exposure (SHE) and postmortem time on glycolytic enzyme activity $(n=8)$ in chicken pectoralis major muscle. For each enzyme, least square means for the enzyme activity of different temperature groups at same postmortem time without a common letter $(x-y)$ differ $(P<0.05)$. Least square means for the enzyme activity of same temperature group at different postmortem time without a common letter $(a-c)$ differ $(P<0.05)$. Standard error for the activity of each enzyme: GPa=5.3, 
$\mathrm{HK}=9.51, \mathrm{PFK} 1=5.09$, and $\mathrm{PK}=0.171$. Abbreviations: $\mathrm{GPa}=$ glycogen phosphorylase $\mathrm{a} ; \mathrm{HK}=$ hexokinase; PFK1 = phosphofructokinase-1; $\mathrm{PK}=$ pyruvate kinase; $N S=$ no significance.

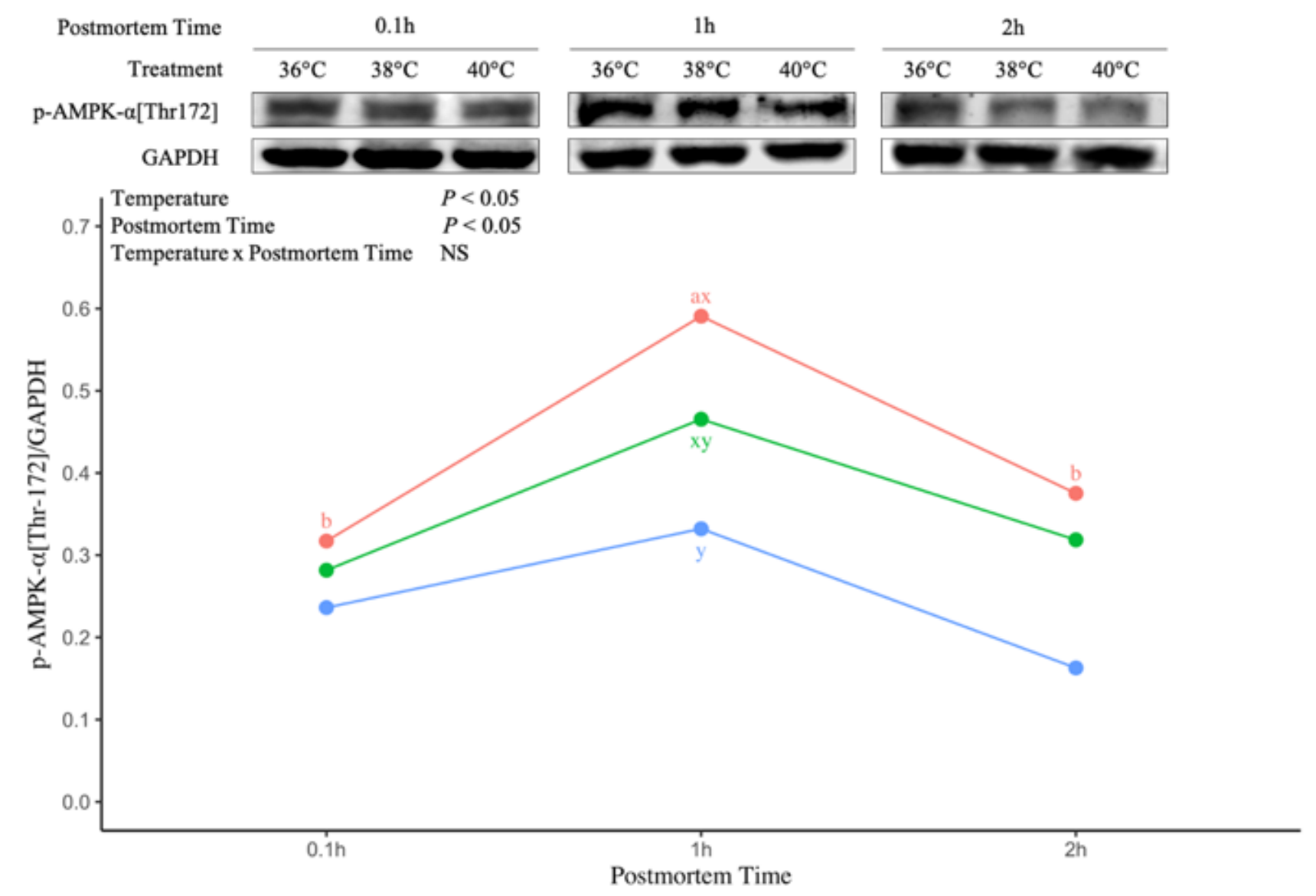

Temperature $\left({ }^{\circ} \mathrm{C}\right) \multimap 36 \multimap 38 \multimap-40$

\section{Figure 3}

Effect of antemortem short-term heat exposure (SHE) and postmortem time on phosphorylation of Thr172 in AMPK a subunit (p-AMPK-a[Thr172]; n=8). Least square means for the p-AMPK-a[Thr172] of different temperature groups at same postmortem time without a common letter $(x-y)$ differ $(P<0.05)$. Least square means for the p-AMPK-a[Thr172] of same temperature group at different postmortem time without a common letter $(a-b)$ differ $(P<0.05)$. Standard error for comparison $=0.0648$. Abbreviations: GAPDH = glyceraldehyde-3-phosphate dehydrogenase; NS = no significance. 